\title{
PREPRINT
}

\section{Taxonomic notes on the Piper pedicellatum C. DC. (Piperaceae)}

\author{
Fan Su, Bao-Duo Wu, Rui Fan, Xun-Zhi Ji, Xiao-Wei Qin, Li-Song Hu, Chao-Yun Hao
}

Disclaimer on biological nomenclature and use of preprints

The preprints are preliminary versions of works accessible electronically in advance of publication of the final version. They are not issued for purposes of botanical, mycological or zoological nomenclature and are not effectively/validly published in the meaning of the Codes. Therefore, nomenclatural novelties (new names) or other nomenclatural acts (designations of type, choices of priority between names, choices between orthographic variants, or choices of gender of names) should NOT be posted in preprints. The following provisions in the Codes of Nomenclature define their status:

International Code of Nomenclature for algae, fungi, and plants (ICNafp)

Article 30.2: "An electronic publication is not effectively published if there is evidence within or associated with the publication that its content is merely preliminary and was, or is to be, replaced by content that the publisher considers final, in which case only the version with that final content is effectively published." In order to be validly published, a nomenclatural novelty must be effectively published (Art. 32.1(a)); in order to take effect, other nomenclatural acts must be effectively published (Art. 7.10, 11.5, 53.5, 61.3, and 62.3).

International Code of Zoological Nomenclature (ICZN)

Article: 21.8.3: "Some works are accessible online in preliminary versions before the publication date of the final version. Such advance electronic access does not advance the date of publication of a work, as preliminary versions are not published (Article 9.9)". 


\title{
Taxonomic notes on the Piper pedicellatum C. DC. (Piperaceae)
}

Fan $\mathrm{Su}^{1,2,3}$, Bao-Duo Wu ${ }^{1,2,3}$, Rui Fan ${ }^{1,2,3}$, Xun-Zhi Ji ${ }^{1,2,3}$, Xiao-Wei Qin ${ }^{1,2,3}$, Li-Song $\mathrm{Hu}^{1,2,3}$, Chao-Yun $\mathrm{Hao}^{1,2,3}$

1 Spice and Beverage Research Institute, CATAS, Wanning, Hainan, 571533, China 2 Ministry of Agriculture Key Laboratory of Genetic Resources Utilization of Spice and Beverage Crops, Wanning, Hainan, 571533, China 3 Key Laboratory of Genetic Improvement and Quality Regulation for Tropical Spice and Beverage Crops of Hainan Province, 571533, China.

Corresponding author: Chao-Yun Hao (haochy79@163.com)

\begin{abstract}
Based on the evidence from morphology, literature survey and specimen examination, Piper curtipedunculum (Piperaceae) is recognized as independent species which is used to be a synonym of Piper pedicellatum. Piper boehmeriifolium var. glabricaule, Piper terminaliflorum and Piper yunnanense are considered as new synonyms of $P$. pedicellatum to which they are similar by a series of morphological characters. And the morphological differences, similarities and geographical ranges of these plant are clarified.
\end{abstract}

\section{Keywords}

Piper, morphology, new synonym, reinstated, taxonomic revision

\section{Introduction}

Piper Linnaeus (1753: 28) is the nominate genus of the family Piperaceae and one of the most diverse lineages among basal angiosperms (Tebbs 1993, Soltis et al. 1999), comprising approximately 2,000 species, mainly distributed in the tropics (Gentry 1982, Kubitzki et al. 1993, Marquis 2004, Quijano-Abril et al. 2014). Asian taxa of Piper have been studied in numerous publications and currently estimated with more than 600 species (Wallich 1824-1849, Blume 1826, Hooker 1886, De Candolle 1910, 1912, 1923, Ridley 1924, Backer and Bakhuizen van den Brink 1963, Long 1984, Huber 1987, Gardner 2006, Suwanphakdee et al. 2006, 2008, 2011, 2012, 2014). Till now, more than 60 species have been recorded in China, half of which are endemic (Gilbert and Xia 1999, Cheng et al. 1999, Gajurel et al. 2001, Hao et al. 2012, Hao et al. 2015, Hao et al. 2017, Hao et al. 2020).

It is hard to identify the specimens of Piper accurately due to polytypic blades, lack of perianth, only tiny bracts, stamens and pistils in the flowers. Moreover, dependening on the herbarium specimens and the insufficient observation to the population variation pattern, there are still some taxonomic problems in Chinese Piper species, such as misapplication of names, unclear species delimitation and improper taxonomic treatment of some species. 
The aim of this paper is to clarify P. pedicellatum, P. curtipedunculum, $P$. boehmeriifolium var. glabricaule, $P$. terminaliflorum and $P$. yunnanense based on our extensive examination of literature studies and detailed observations on the field populations. The related articles of International Code of Nomenclature(ICN) (Turland et al. 2018) were followed for nomenclature changes.

\section{Material and methods}

Original publications and descriptions of $P$. pedicellatum, $P$. curtipedunculum, $P$. boehmeriifolium var. glabricaule, P. terminaliflorum and $P$. yunnanense were obtained from the literature survey of the library, Tropicos ( http://www.tropicos.org/), Biodiversity Heritage Library (https://www.biodiversitylibrary.org/), JES (https://www.jse.ac.cn/), Jstor (https://www.jstor.org/), CVH (https://www.cvh.ac.cn/index.php) and other data. Label information was also recorded.

We examined specimens that kept in all the major Chinese herbaria, holotype especially, including IBSC, KUN, NAS and PE, and in some non-Chinese herbaria as well, including A, B, E, G, K, MO, P and US. The size and shape of leaves and inflorescences were studied first. Then the details of flowers and fruits were examined. Through the study of a large number of specimens, the morphological character variation pattern, phenology, habitat and other information of those plants were preliminarily understood, which laid a foundation for field work.

The basic distribution data and photographs of the those plants were collected during our fieldwork from 2012 to 2021 in Yunnan province of China. The habitat was photographed and some of major morphological characters were measured, such as plant life form, size and shape of the leaves and inflorescences, details of flowers and fruits, form of the floral bracts and others.

\section{Results}

Piper curtipedunculum C. DC. in Notizbl. Bot. Gart. Berlin-Dahlem: 481. 1917. Figure 1, 2 ; Table 1

Type. CHINA. Yunnan Province, Mengzi, Elevation:1829 m, A. Henry 10438 (holotype: B [B100294777!]; isotypes: A [A00005900!], E [E00318488!]; G [G00314149!]; K [K000794373!]; MO [MO-150824!]; US [US 00105456!]).

Note. De Candolle (1917) described Piper curtipedunculum (Piperaceae) based on A. Henry 10438 (A, B, E; Fig. 1 A-C), from Mengzi, southeastern Yunnan province, China. Piper pedicellatum C. DC.(1866) was also described by De Candolle based on specimens from Bangladesh, with A. Henry 9482A (B; Fig. 1 D-F) being the holotype. Y.C. Tseng (1979) published a new distribution of $P$. pedicellatum in China, in Acta Phytotaxonomica Sinica, who stated that the species was similar to $P$. 
curtipedunculum, but differs from it by leaves 7-9 veins, 3 of which emanate from the base; Pedicels often as long as petioles; bracts large, 1-1.2 $\mathrm{mm}$ in diameter (leaves 7-9 veins, 5-7 of which emanate from the base; Pedicels length, often twice as long as petioles; bracts $0.5-1 \mathrm{~mm}$ in diameter). M.G. Gilbert and N.H. Xia(1999) considered that the difference was small between the two species and $P$. curtipedunculum was consdered as a synonym of $P$. pedicellatum in Flora of China.

In the protologue, we found that both of them were described as liana and no significant characteristic difference by De Candolle. However, P. curtipedunculum can easily be distinguished from $P$. pedicellatum by several morphological characters. We examined the holotype and origin specimens of both names and found that $P$. pedicellatum were subshrubs and P. curtipedunculum were woody lianas. Morphology of leaves, inflorescences and fruits were obviously different. Field observation and examination on the different populations of both species showed that P. pedicellatum and P.curtipedunculum were differ significantly in their leaf blade shape (ovate or narrowly ovate to broad elliptic vs. trophophyll leaf blade lanceolate, gonophyll leaf blade broad lanceolate to ovate), leaf blade texture (papery, rough vs. leathery, glossy), infructescence size (length $4-10 \mathrm{~cm}, 7-11 \mathrm{~mm}$ in diameter vs. length $5-10 \mathrm{~cm}$, 3-4 $\mathrm{mm}$ in diameter), mature berries (obovate, 4-angled, 2-3 $\mathrm{mm}$ in diameter, red vs. globose, 0.8-1.2 $\mathrm{mm}$ in diameter, green), and stigmas (3 or 4 vs. 3)(Figure 1, Table 1). 

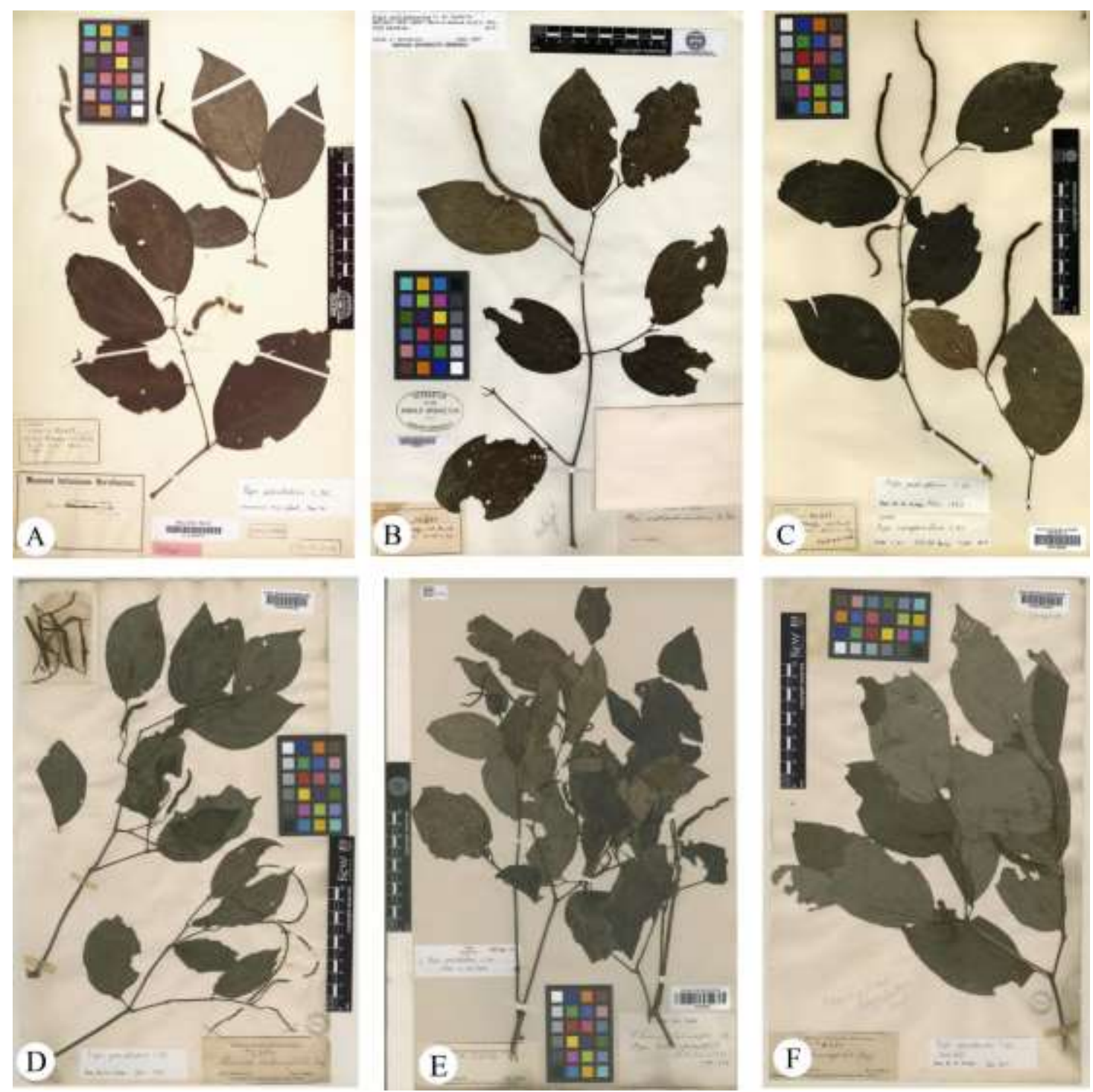

FIGURE 1. A-C Type of P. curtipedunculum C. DC., Mengzi Yunnan Province, A holotype, B100294777; B-C isotype, A00005900, E00318488, respectively. D-F Type of $P$. pedicellatum C. DC., Bangladesh, D lectotype, K000794428; E isolectotype, P01656299; F Syntype, K000794427. 
Table 1. Comparative features of $P$. curtipenduculum and P. pedicellatum

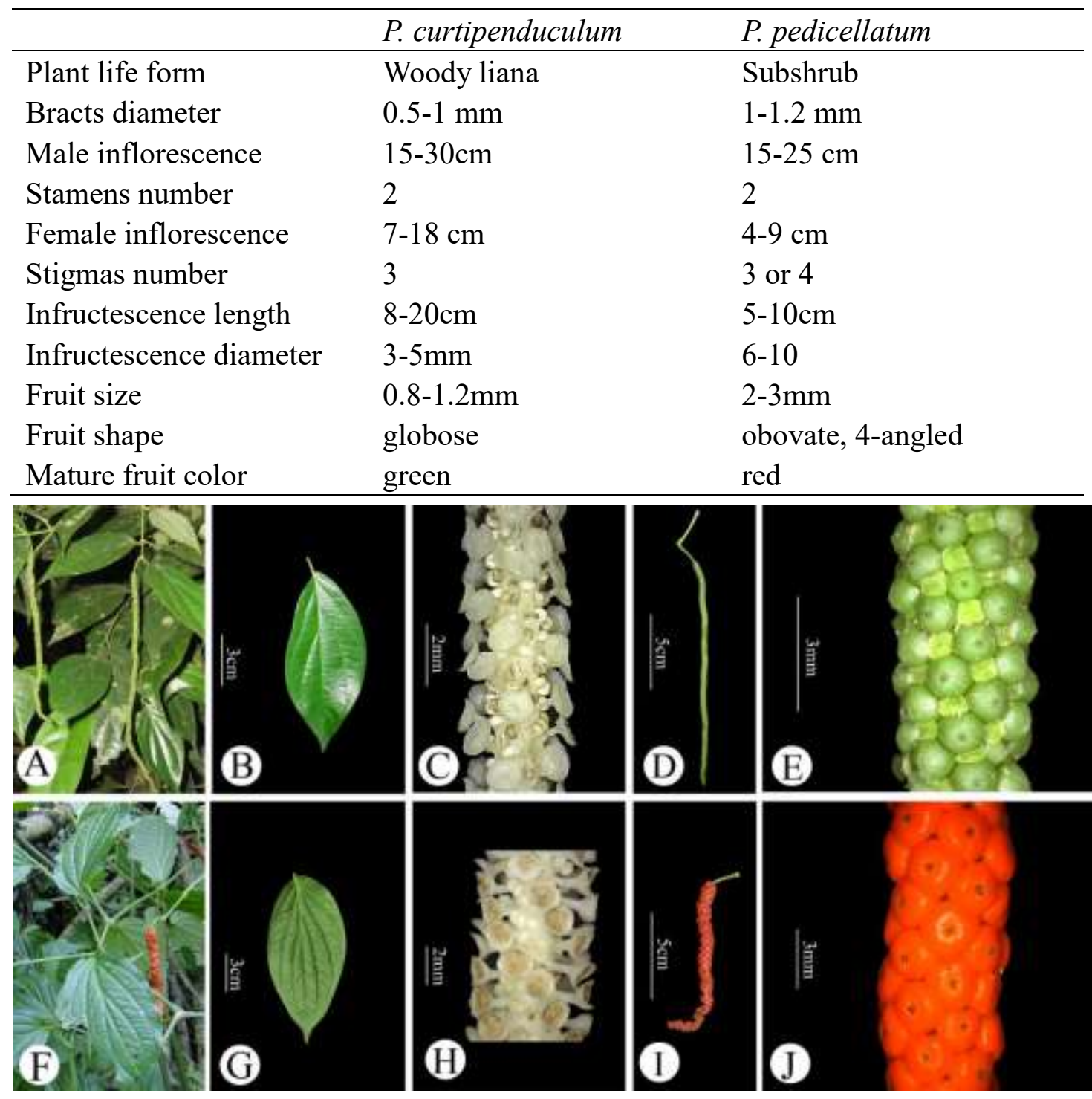

FIGURE 2. A-E P. curtipedunculum C. DC. in the wild (Xishuangbanna, Yunnan). A Branch with infructescence; B Adaxial of gonophyll; C Detail of male Spike; D infructescence; E Detail of infructescence. F-J P. pedicellatum C. DC. In the wild (Gaoligong mountains, Baoshan, Xishuangbanna, Yunnan). F Branch with infructescence; G Adaxial of gonophyll; H Detail of male Spike; I infructescence; J Detail of infructescence.

Piper pedicellatum C. DC., J. Bot. 4: 164. 1866. Figure 3; Table 2.

Piper glabricaule C. DC., Notizbl. Bot. Gart. Berlin-Dahlem 6: 477. 1917. Piper boehmeriifolium var. glabricaule (C. DC.) M.G. Gilbert \& N.H. Xia, Novon 9(2): 191. 1999. Type: CHINA, Yunnan, Mengzi, elevation: 1524 m, A. Henry $9482 A$ (holotype: B [B100294885!]; isotypes: A [A00005904!]; G [G barcode 00314823!], K [ K000575306!]; US [US00106402!]). 
Piper terminaliflorum Y.Q. Tseng, Acta Phytotax. Sin. 17(1): 30 - 31,f.7.1979. Type: CHINA,Yunnan, Feng-qing, elevation 2200 m, 24 June 1938, T.T.Yü 16454 (holotype:PE [PE00002934!]; isotypes: A [A 00005913!]). syn.nov.

Piper yunnanense Y.Q. Tseng, Acta Phytotax. Sin. 17(1): 32. f. 9. 1979. Type: CHINA, Yunnan, Shuangjiang, elevation 1100-2000 m, nearby the stream in the forest ; 22 September 1957, G. S. Xin 1132 (holotype:IBSC [0000687!]; isotypes: NAS [00070272!]; KUN [KUN0435506, KUN0435507!]).

Type. BANGLADESH, Bengalia Orient, Griffith 4404 (lectotype: K [K000794428!]; isolectotype: P [P01656299!]).

Note. Piper glabricaule C. DC. was designated based on only one specimen in branch with male spike (Fig. 3A) by De Candolle (1917) from Mengzi, altitudes 1524 m, Yunnan province in China. M.G. Gilbert and N.H. Xia (1999) reduced $P$. glabricaule to a variety of Piper boehmeriifolium mainly because the former is different in leaf morphology and infructescence size. According to the original description, $P$. glabricaule is more similar to $P$. pedicellatum with slight differences in leaf morphology. There should be two extremes of a continuum of material and the leaves are often transitional and not well demarcated in the wild.

The type specimens of Piper terminaliflorum Y.Q. Tseng and Piper yunnanense Y.Q. Tseng were both collected from Lincang of Yunnan Province in China by Y.Q. Tseng (1979). Y.Q. Tseng stated that the Piper terminaliflorum was similar to $P$. glabricaule, but differed by its inflorescences insertion patterns. M.G. Gilbert and N.H. Xia (1999) considered that the difference was small between P. terminaliflorum and $P$. boehmeriifolium and placed $P$. terminaliflorum as a synonym of $P$. boehmeriifolium in Flora of China. During 2012 to 2021, we carried out continuous field investigation of Piper speceis in Lincang and Mengzi, Yunnan Province. And we also compared the type of specimens and protologue of these four plants. The results showed that the life form, leaves shape and texture, finely glandular, base oblique, veins number, inflorescence structure and length, fruit shape and size vary continuously and have no much distinct morphological difference (Table 2, Fig. 3). In addition, the type localities of the four species are not far away from each other. These available evidence indicate that these species are actually conspecific. $P$. pedicellatum is different from $P$. boehmeriifolium by its leaf blades ovate or narrowly ovate to elliptic, base broadly cuneate or suborbicular, bilateral difference $2-3 \mathrm{~mm}$, apex acute to acuminate, female spikes $6.5-8 \mathrm{~mm}$ thick in fruit ( leaf blades narrowly elliptic, oblong, oblong-lanceolate, base oblique, bilateral difference 5-10 mm, apex acute to long acuminate, female spikes 3-3.5 mm thick in fruit )(Fig. 1D, Fig. 3E-G). 
Table 2. Comparative features from the original description and holotype.

\begin{tabular}{|c|c|c|c|c|}
\hline & P. pedicellatum & P. glabricaule & P. terminaliflorum & P. yunnanense \\
\hline Plant life form & Subshrub & Subshrub & Subshrub & Subshrub \\
\hline Leaves shape & $\begin{array}{l}\text { ovate or narrowly ovate to } \\
\text { elliptic }\end{array}$ & $\begin{array}{l}\text { elliptic, narrowly elliptic, or } \\
\text { oblong }\end{array}$ & Oval or broad oval & $\begin{array}{l}\text { ovate, those at } \\
\text { apex of stem elliptic }\end{array}$ \\
\hline Leaves texture & chartaceous, glandular & chartaceous, glandular & chartaceous, glandular & chartaceous, glandular \\
\hline Veins number & $7-9$ & $9-10$ & 9 & 9 \\
\hline Bracts & Orbicular, peltate & Orbicular, peltate & Orbicular, peltate & Orbicular, peltate \\
\hline Male inflorescence & N.A. & $15-21 \mathrm{~cm}$ & $14-16 \mathrm{~cm}$ & N.A \\
\hline Female inflorescence & $4-5 \mathrm{~cm}$ & $6-8 \mathrm{~cm}$ & N.A & $4-8 \mathrm{~cm}$ \\
\hline Infructescence length & $4-12 \mathrm{~cm}$ & $6-12 \mathrm{~cm}$ & N.A & $4-8 \mathrm{~cm}$ \\
\hline Fruit size & Berry obovate, 4-angled & Berry obovate, 4-angled. & N.A & Berry obovate, 4-angled. \\
\hline Holotype locality & Bengalia Orient & Mengzi, Yunnan & Feng-qing, Yunnan & Shuangjiang, Yunnan \\
\hline Elevation range & $1000-1900 \mathrm{~m}$ & $500-1900 \mathrm{~m}$ & $1600-2200 \mathrm{~m}$ & $1100-2000 \mathrm{~m}$ \\
\hline
\end{tabular}




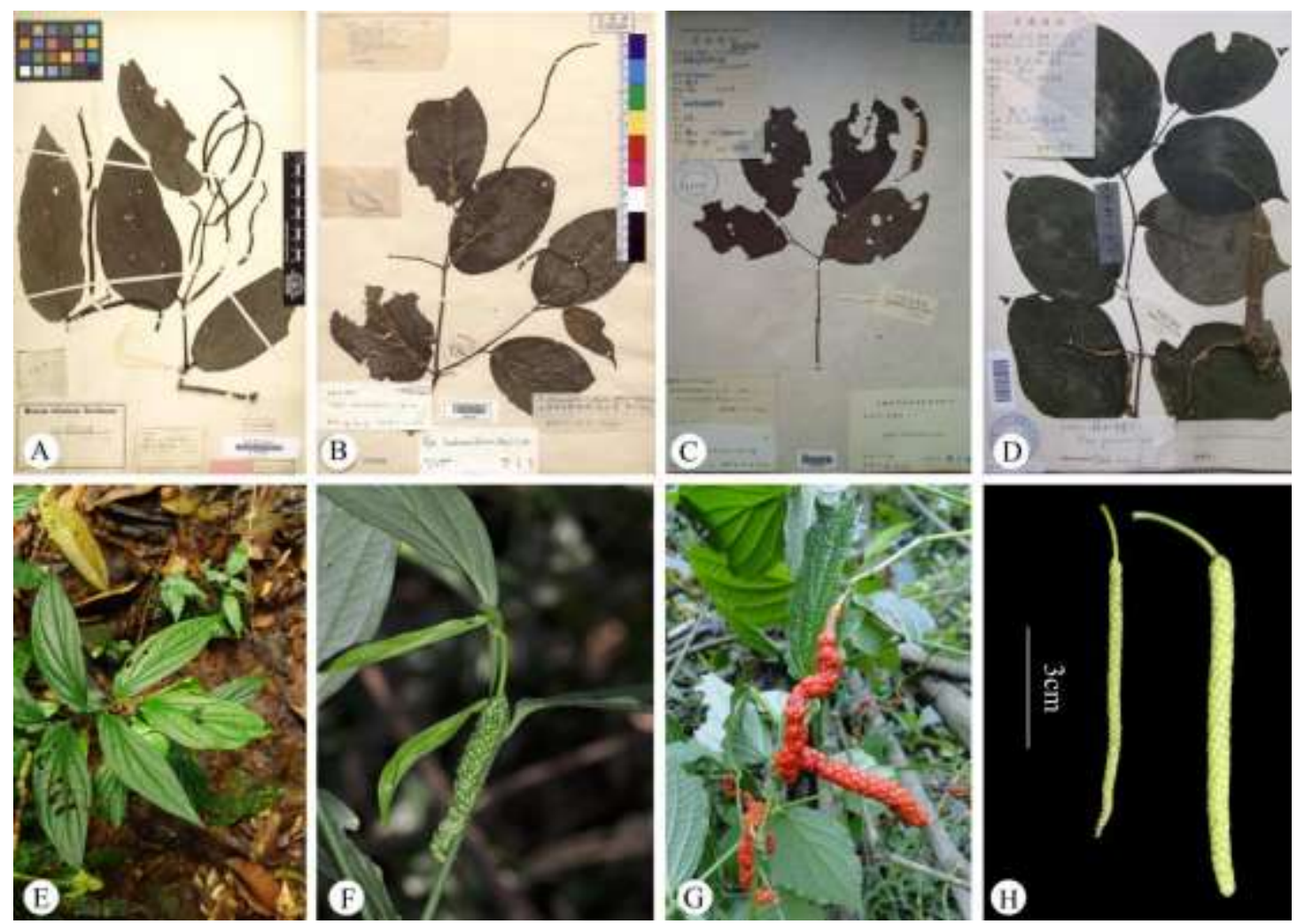

FIGURE 3. A-C Holotype of $P$. boehmeriifolium var. glabricaule, $P$. terminaliflorum and $P$. yunnanense respectively; D Isotype of P. yunnanense; E-F Habitat and Branch with infructescence of $P$. boehmeriifolium in the wild (Xishuangbanna, Yunnan); G $P$. pedicellatum in the wild (Jingdong wuliang mountain, Puer, Yunnan); H Comparison of unripe infructescence between P. pedicellatum(Left) and P. boehmeriifolium(Right)

\section{Acknowledgements}

This work was supported by China Agriculture Research System (Project No. CARS - 11) and the National Science Foundation of China (Project No. 31201263). We would like to thank Jing Li for valuable comments on the manuscript. We are also grateful to Jin-Tao Xu and Xin-Yue Yang for field assistance. 


\section{References}

Backer CA, Brink RC Bakhuizen Van Den (1963) Flora of Java (Spermatophytes Only), Vol. 1 (Gymnospermae, families 1-7, angiospermae, families 8-110). P. Noordhoff N. V., Groningen, 648.

Blume CL (1826) Monographie der Oost-Indische Pepersooten, Vol. 11. Bataviaasch Genootschap van Kunsten en Wetenschappen, Bataviaasch 139-245.

Cheng YQ, Xia NH, Gilbert MG (1999) Piperaceae. In: Wu ZY, Raven PH (Eds.) Flora of China, Vol. 4. Science Press, Beijing \& Missouri Botanical Garden Press, St. Louis, 110-141.

De Candolle C (1866) Piperaceae novae. Journal of Botany, British and Foreign. vol. 4: Robert Hardwicke, London, 161-167. https://www.biodiversitylibrary.org/item/54910

De Candolle C (1910) A revision of Philippine Piperaceae. Philippine Journal of Science 5: 405-463.

De Candolle C (1912) Piperaceae novae E Peninsula Malayana. Records of the Botanical Survey of India 6 (1): 1-27.

De Candolle C (1917) Piperaceae Chinese. Notizblatt des Königl. Botanischen Gartens und Museums zu Berlin. Botanischer Garten und Botanisches Museum, Berlin-Dahlem, bd.6 :476-482. https://www.biodiversitylibrary.org/item/91220

De Candolle C (1923) Piperacearum clavis analytica. Vol.1.Genève :Conservatoire Botanique 65-415.

Gajurel PR, Rethy P, Kumar Y (2001) A new species of Piper (Piperaceae) from Arunachal Pradesh, north-eastern India. Botanical Journal of the Linnean Society 137: 417-419. http://dx.doi.org/10.1111/j.1095-8339.2001.tb02337.x

Gardner RO (2006) Piper (Piperaceae) in the Philippine islands: The climbing species. Blumea 51: 569-586. http://dx.doi.org/10.3767/000651906X622139

Gentry AH (1982) Phytogeographic patterns as evidence for a Chocó refuge. In: Prance GT (Ed.) Biological diversification in the tropics. Columbia University Press, New York, 121.

Gilbert M, Xia NH (1999) Notes on the Piperaceae of China. Novon 9: 190-198.

Hao CY, Tan LH, Fan R, Yu H, Yang JF, Wu HS (2012) Floristic geography of Piper (Piperaceae) in China. Plant Diversity and Resources 34 (5): 421-429. https://doi.org/10.3724/SP.J.1143.2012.12040

Hao CY, Tan YH, Hu LS, Tan LH, Chen HP, Qin XW, Wu G, Wu HS (2015) Piper peltatifolium, a new species of Piperaceae from Hainan, China. Phytotaxa 236 (3): 291-295. https://doi.org/10.11646/phytotaxa.236.3.12

Hao CY, Qin XW, Tan LH, Hu LS (2017) Piper jianfenglingense, a new species of Piperaceae from Hainan Island, China. Phytotaxa 331(1): 109-116.

Hao CY, Wu BD, Qin XW, Wu G, Deng HY, Tan YH (2020) Morphological and molecular evidence for a new species from China. Phytotaxa 429(3): 191-199. 
Hooker JD (1886) Piperaceae. In: Hooker JD (Ed.) Flora of British India, Vol. 5. Reeve \& Co., London, 78-97.

Huber H (1987) Piperaceae. In: Dassanayake MD (Ed.) A Revised Handbook to the Flora of Ceylon, Vol. 6. Amerind Publishing, New Delhi, 272-300.

Linnaeus C (1753) Species Plantarum, Vol. 1. Impensis Laurentii Salvii, Stockholm, 1200.

Long DG (1984) Piperaceae. In: Grieson AJC, Long DG (Eds) Flora of Bhutan, Vol. 1, Pt. 2. Royal Botanic Garden, Edinburgh, 342-351.

Marquis RJ (2004) Biogeography of Neotropical Piper. In: Dyer LA, Palmer ADN (Eds) Piper: A model genus for studies of phytochemistry, ecology, and evolution. Kluwer Academic/ Plenum Publishers, New York, 78-96. https://doi.org/10.1007/978-0-387-30599-8_5

Quijano-Abril MA, Mejí a-Franco FG, Callejas-Posada R (2014) Panbiogeographic analysis of Enckea (Piperaceae), a small dry forest clade in the phylogeny of a big rainforest genus. Revista Mexicana de Biodiversidad 85 (1): 98-107. https://doi.org/10.7550/rmb.37002

Ridley HN (1924) The Flora of the Malay Peninsula, Vol. 3. L. Reeve \& Co., London, $25-51$.

Soltis PS, Soltis DE, Chase MW (1999) Angiosperm phylogeny inferred from multiple genes as a tool for comparative biology. Nature 402(6760), 402-404. https://doi.org/10.1038/46528

Suwanphakdee C, Masuthon S, Chantaranothai P, Chayamarit K, Chansuvanich N (2006) Notes on the genus Piper L. (Piperaceae) in Thailand. Thai Forest Bulletin (Botany) 34(5): 206-214.

Suwanphakdee C, Chantaranothai P (2008) A further note on the genus Piper L. (Piperaceae) from Thailand. Natural History Journal of Chulalongkorn University 8 (2): 205-209.

Suwanphakdee C, Chantaranothai P (2011) A new species and three taxonomic changes in Piper (Piperaceae) from Thailand. Blumea 56(3):235-239.

Suwanphakdee C, Simpson DA, Chantaranothai P (2012) Three new species of Piper (Piperaceae) from Thailand. Thai Forest Bulletin, Botany 40: 31-37. http://dx.doi.org/10.1360/aps040163

Suwanphakdee C, Chantaranothai P (2014) Two new species of Piper (Piperaceae) from Thailand. Novon 23 (2): 230-235. http://dx.doi.org/10.3417/2011069

Tebbs MC (1993) Piperaceae. In: Kubitzki K, Rohwer JG, Bittrich V (Eds) The Families and Genera of Vascular Plants. II. Flowering Plants: Dicotyledons, Magnoliid, Hamamelid and Caryophyllid Families. Springer, Berlin, 516-520.

Tebbs MC (1993) Piperaceae. In: Kubitzki K, Rohwer JG, Bittrich V (Eds) The families and genera of vascular plants. II. Flowering plants: Dicotyledons, Magnoliid, Hamamelid and Caryophyllid families. Springer, Berlin, 516-520. https://doi.org/10.1007/978-3-662-02899-5_60

Tseng YQ (1979) Materials for Chinese Piper. Acta Phytotaxonomica Sinica 17(1): $32-33$. 
Turland NJ, Wiersema JH, Barrie FR, Greuter W, Hawksworth DL, Herendeen PS, Knapp S, Kusber WH, Li DZ, Marhold K, May TW, McNeill J, Monro AM, Prado J, Price MJ, Smith GF (2018) International Code of Nomenclature for algae, fungi, and plants (Shenzhen Code) adopted by the Nineteenth International Botanical Congress Shenzhen, China, July 2017. Koeltz Botanical Books 159.

Wallich N (1828-1849) A numerical list of dried specimens of plants in the East India Company's Museum. Collected under the superintendence of Dr. Wallich of the Company's Botanic Garden at Calcutta, London. 